УДК $581.9(477.74)$

О. Ю. Бондаренко, старший викладач

Т. В. Васильєва, к.б.н., доцент

ОНУ імені І. І. Мечникова, кафедра ботаніки, вул. Дворянська, 2, Одеса, 65082, Україна

\title{
СТРУКТУРА СИНАНТРОПНОЇ ФЛОРИ МАЛИХ РІЧОК ПОНИЗЗЯ МЕЖИРІЧЧЯ ДНІСТЕР - ТИЛІГУЛ
}

\begin{abstract}
Досліджено особливості синантропної флори долин малих річок у пониззі межиріччя Дністер - Тилігул. Виявлено 291 вид синантропних рослин, що складає 55,7 \% від загальної кількості видів. Для долини річки Великий Куяльник характерна найбільша кількість синантропних видів $(61,8 \%)$, для p. Тилігулу - найменша $(51,9 \%)$. У всіх флорах домінують види апофітної фракції (31,7 \%-38,5 \%). Усі досліджені флори долин невеликих річок можна характеризувати як трансформовані.
\end{abstract}

Ключові слова: синантропна флора, долини малі річки, Дністер, Тилігул.

Поява та існування синантропних рослин є причиною низки проблем не лише для господарського комплексу, а й загалом - для природного флористичного різноманіття регіонів. У той же час, цінність таких видів полягає також у формуванні піонерних угруповань на трансформованих ділянках, де у подальшому створюються умови для відновлювальних процесів [22].

Пошук, інвентаризація, всебічне вивчення синантропних видів рослин нині залишається актуальною темою $[1-7 ; 10 ; 13 ; 14 ; 16 ; 17 ; 21,28 ; 29]$. Однак, аспекти цього питання, які б сприяли створенню цілісної картини для флори Одеської області, висвітлені не в повній мірі.

Хоча територія Півдня України досить сильно змінена, немала частина помірно трансформованих ділянок зі рештками природної флори наявна у долинах малих річок.

На території Одеської області нараховується 1143 річки і їх притоки; більше 75 малих річок мають довжину 10 км, з них лише п'ять - більше 100 км. Малі річки межиріччя беруть початок на південних околицях Волино-Подільської і Молдавської височин, мають вузькі басейни, незначну протяжність і впадають у прибережні лимани. Схили їх долин сильно порізані сіткою балок та ярів [20;23].

Річковий режим малих річок маловодний і визначається місцевими фізикогеографічними умовами - вони живляться, переважно, за рахунок опадів. У посушливі роки, а особливо влітку - вони пересихають. Згінно-нагінні явища призводять до коливання рівня води в межах 50 см. Внаслідок цих процесів русла малих річок замулюються, заростають і втрачають дренуючу здатність $[15 ; 20]$. 
У рослинному покриві коротко- та середньозаплавних ділянок (дещо менше - знижених ділянок грив та заплавних грив) невеликих річок, переважають засолені луки, які у флорі плавнево-літорального ландшафту (ПЛЛ) Причорномор'я за площею займають третє місце [14].

Метою роботи була оцінка сучасного стану флори долин чотирьох малих річок у пониззі межиріччя Дністер - Тилігул за рівнем синантропізації їх флор.

У завдання досліджень входило:

1. Визначити видовий склад флори долин малих річок: Балай, Свинна, Тилігул та Великий Куяльник і виділити синантропні види.

2. Проаналізувати синантропні види дослідженої флори за хронотипом.

3. Виділити алвентивну та апофітну фракції флори

4. Порівняти отримані результати із даними щодо флори регіону.

\section{Матеріали та методи}

Вивчення флори проводили маршрутним методом протягом 2003-2013 років. Обстежувана територія відноситься до Одеського геоботанічного округу злакових і полиново-злакових степів, засолених лук, солончаків та рослинності карбонатних відслонень [12].

Видову приналежність рослин встановлювали за «Определитель...» [19] та численною фаховою літературою, номенклатурні назви видів наведені за довідником [27].

Назви річок наведені за «Каталогом річок ...» [24]. Під «долинами» малих річок розуміємо всі їх складові: дно (ложе долини), тальвег, русло, заплаву, схили долини, тераси та бровку [24].

Ступінь натуралізації або адаптації синантропних видів рослин у змінених екотопах та час потрапляння видів адвентивної фракції на територію України, встановлювали за довідковою літературою [22; 26].

Д. В. Дубина, Ю. Р. Шеляг-Сосонко [14] використовують поняття «малі річки». У літературному огляді ми зберегли авторську термінологію. Проте, враховуючи існуючі нормативи щодо визначення «мала» річка [24], для характеристики досліджуваних річок використовували узагальнююче поняття «невелика» річка, оскільки всі вони належать до різних категорій величини річок, але не $є$ «великими», такими як Дунай чи Дністер.

Так, річка Свинна, яка впадає у Хаджибейський лиман, має довжину 41 км

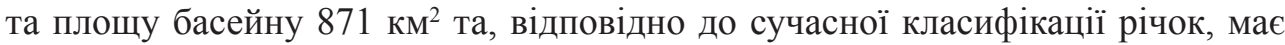
характеризуватися як «мала» річка [24]. Річка Великий Куяльник, що впадає

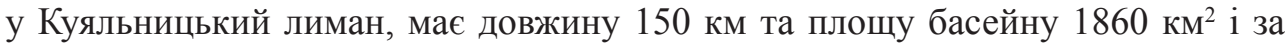
цими параметрами знаходиться у проміжку між «мала» і «середня» річка. Річка Тилігул впадає у Тилігульський лиман, має протяжність 173 км та 3550 км² площу басейну та повинна характеризуватися як «середня» річка. Річка Балай 
(Балайчук), яка також впадає у Тилігульский лиман та має більш-менш виражене русло, має характеризуватися як «мала».

Всі згадані річки мають виражені долини, представлені різноманітними екотопами з різним ступенем антропогенного навантаження, що робить їх цікавими у флористичному відношенні.

До флористичного різноманіття річкових долин використовували загальний термін «флора» у розумінні Б. А. Юрцева [25] з деякими уточненнями Я. П. Дідуха [11]. Таким чином, флору долини окремої річки характеризували як «... багатство популяцій видів рослин, які у своїй сукупності відображають її властивості та які населяють певну територію у природних межах» [11].

\section{Результати та обговорення}

Отримані результати базуються на багаторічному вивченні флори пониззя межиріччя Дністер - Тилігул в межах Одеського геоботанічного округу.

За результатами досліджень, флора долин невеликих річок пониззя межиріччя Дністер - Тилігул в межах Одеського геоботанічного округу представлена 522 видами (табл. 1). Їх кількість, становить 60,6 \% видів флори межиріччя, або ж - 25,8 \% видів Північного Причорномор'я [18].

Це дещо перевищує вже існуючі дані для малих річок флори геокомплексів всього ПЛЛ. Причорномор'я, де кількість видів становить 505 видів [14].

Частка синантропних видів рослин у флорі долин малих річок становить 291 вид (55,7 \% загальної кількості видів). Аналогічний показник для всієї флори пониззя межиріччя Дністер - Тилігул є лише 51,0 \%.

Серед флор обстежуваних долин річок найбільшу кількість видів відмічено для річки Великий Куяльник (322 види, або 61,7 \% загальної кількості видів флори невеликих річок).

На схилах долин цієї річки збереглося доволі багато природних ділянок із зональною та інтразональною флорою, проте часткова зарегульованість русла річки, інтенсивний антропогенний вплив поблизу численних селищ на ії̈ узбережжі можуть бути причиною появи та існування тут значної кількості синантропних видів рослин (61,8 \% видів іiі флори).

Протяжність річки Балай не є надто великою, проте, на схилах, у заплаві, терасах долини є досить багато збережених природних ділянок, у пониззі розміщується Петровський ліс, тому і флористичне різноманіття тут також - доволі високе (294 види; 56,3 \%). За кількістю синантропних видів рослин флора долини р. Балай також знаходиться на другому місці (56,1%).

Найменша кількість видів загалом, як і найменша кількість синантропних рослин, представлена для флори долини р. Тилігул. Проте, отримані дані можна пояснити невеликим розміром ії ділянки у межах дослідженої території.

Для флори пониззя межиріччя Дністер - Тилігул виділено 38 видів, які також мають вважатися синантропними, оскільки є рослинами, що у регіоні 
представлені в екотопах різних класів антропогенних екосистем: зокрема - на трансформованих узбіччях залізничних колій, на засіяних полях (в якості сегетальних бур'янів) тощо [9].

Таблиця 1

Розподіл синантропних видів у флорах долин малих річок межиріччя

\begin{tabular}{|c|c|c|c|c|c|c|c|c|c|c|}
\hline \multirow{3}{*}{$\begin{array}{c}\text { Фракції і групи } \\
\text { синантропних } \\
\text { видів }\end{array}$} & \multicolumn{10}{|c|}{ Малі річки } \\
\hline & \multicolumn{2}{|c|}{ Балай } & \multicolumn{2}{|c|}{ Свинна } & \multicolumn{2}{|c|}{ Тилігул } & \multicolumn{2}{|c|}{ В. Куяльник } & \multicolumn{2}{|c|}{ Загалом } \\
\hline & $\begin{array}{c}\text { Абс. } \\
\text { число }\end{array}$ & $\%$ & $\begin{array}{c}\text { Абс. } \\
\text { число }\end{array}$ & $\%$ & $\begin{array}{c}\text { Абс. } \\
\text { Число }\end{array}$ & $\%$ & $\begin{array}{l}\text { Абс. } \\
\text { число }\end{array}$ & $\%$ & $\begin{array}{c}\text { Абс. } \\
\text { число }\end{array}$ & $\%$ \\
\hline Хронотип & 61 & 20,8 & 45 & 16,1 & 34 & 18,0 & 71 & 22,1 & 119 & 22,8 \\
\hline Археофіти & 32 & 10,9 & 24 & 8,6 & 20 & 10,6 & 35 & 10,9 & 59 & 11,3 \\
\hline Кенофіти & 29 & 9,9 & 21 & 7,5 & 14 & 7,4 & 36 & 11,2 & 60 & 11,5 \\
\hline Адвентивна & 64 & 21,8 & 47 & 16,8 & 37 & 19,7 & 73 & 22,7 & 126 & 24,1 \\
\hline Ергазіофіти & 13 & 4,4 & 4 & 1,4 & 5 & 2,7 & 7 & 2,2 & 19 & 3,6 \\
\hline Епекофіти & 31 & 10,5 & 27 & 9,7 & 19 & 10,1 & 46 & 14,3 & 66 & 12,6 \\
\hline Агріофіти & 19 & 6,5 & 16 & 5,7 & 13 & 6,9 & 19 & 5,9 & 39 & 7,5 \\
\hline Ефемерофіти & 1 & 0,3 & - & - & - & - & 1 & 0,3 & 2 & 0,4 \\
\hline Апофітна & 99 & 33,8 & 97 & 34,8 & 60 & 31,8 & 124 & 38,5 & 162 & 31,1 \\
\hline Евапофіти & 14 & 4,8 & 15 & 5,4 & 3 & 1,6 & 13 & 4,0 & 22 & 4,2 \\
\hline Геміапофіти & 65 & 22,1 & 66 & 23,7 & 48 & 25,4 & 87 & 27,0 & 111 & 21,3 \\
\hline $\begin{array}{l}\text { Апофіти ви- } \\
\text { падкові }\end{array}$ & 20 & 6,8 & 16 & 5,7 & 9 & 4,8 & 24 & 7,5 & 29 & 5,6 \\
\hline $\begin{array}{l}\text { Види з прогре- } \\
\text { сивним типом } \\
\text { ареалу }\end{array}$ & 2 & 0,7 & 3 & 1,1 & 1 & 0,5 & 2 & 0,6 & 3 & 0,6 \\
\hline Синантропні & 165 & 56,1 & 147 & 52,7 & 98 & 51,9 & 199 & 61,8 & 291 & 55,7 \\
\hline Загалом видів & 294 & 100,0 & 279 & 100,0 & 189 & 100,0 & 322 & 100,0 & 522 & 100,0 \\
\hline
\end{tabular}

Для флори пониззя межиріччя їх виділено 38 видів. У флорах долин малих річок пониззя межиріччя Дністер - Тилігул, трапляються 25 із них: Apiaceae (Селерові): Seseli tortuosum L. (жабриця звивиста); Asteraceae (Айстрові): Centaurea orientalis L. (волошка східна), Crepis ramosissima D'Urv. (скерда галузиста), Sonchus palustris L. (жовтий осот болотний), Tragopogon major Jacq. (козельці великі), Tragopogon tesquicola Klokov (козельці пустельні), Xeranthemum annum L. (безсмертки однорічні); Brassicaceae (Капустяні): Erysimum diffusum Ehrh. (жовтушник розлогий); Caryophyllaceae (Гвоздичні): Arenaria viscida Hall. f. ex Lois. (піщанка уральська), Herniaria besseri Fisch. ex Hornem. (остудник Бессера), Spergularia media (L.) C. Presl (стелюшок середній); Chenopodiaceae (Лободові): Kochia prostrate (L.) Schrad. (віниччя сланке); Convolvulaceae (Берізкові): Convolvulus cantabrica L. (березка кантабрійська); Cyperaceae (Осокові): Bolboschoenus maritimus (L.) Palla (бульбокомиш морський), 
B. Maritimus (L.) Palla var. compactus (Hoffm.) T. V. Egorova (бульбокомиш скучений); Fabaceae (Бобові): Medicago romanica Prodán. (люцерна румунська); Juncaceae (Ситниковi): Juncus gerardii Loisel. (ситник Жерара); Lamiaceae (Глухокропивові): Stachys recta L. (чистець прямий), Teucrium polium L. (самосил білоповстистий); Linaceae (Льонові): Linum hirsutum L. (льон шорсткий); Poaceae (Тонконоговi): Calamagrostis epigeios (L.) Roth (куничник наземний), Phragmites australis (Cav.) Trin. ex Steud. (очерет звичайний), Poa angustifolia L. (тонконіг вузьколистий), Poa pratensis L. (тонконіг лучний); Scrophulariaceae (Ранникові): Linaria maeotica Klokov (льонок азовський).

Відмінність регіональних екологічних умов, урізноманітнення місцезростань, внаслідок фрагментації рослинного покриву, є основою для появи нових синантропних видів, їх натуралізації та адаптації.

Для всіх флор долин досліджуваних річок встановлено переважання кількості видів апофітної фракції над адвентивною. Для річки Свинної цей показник $€$ найбільшим (1:2,0), для інших річок співвідношення дещо менше: Великий Куяльник 1:1,7, Балай та Тилігул - по 1:1,6. Для флори малих річок, загалом, співвідношення становить лише 1:1,3, що співпадає 3 даними щодо показника для флори пониззя межиріччя Дністер - Тилігул [7].

Таким чином, флора малих річок більш синантропізована, ніж флора досліджуваного межиріччя і частка синантропних видів тут є вищою, за рахунок видів апофітної фракції.

Проведений аналіз дав змогу констатувати, що більшість видів адвентивної фракції для всіх флор є епекофітами: від 9,7 \% видів у флорі річки Свинна до 14,3 \% у флорі Великий Куяльник порівняно з 12,6 \%, характерними для флори малих річок в цілому. Таким чином, у адвентивній фракції спостерігається домінування видів, які натуралізуються переважно на трансформованих ділянках.

За даними Д. В. Дубини [14], на кінець 1980-х років частка епекофітів для флори малих річок ПЛЛ. Причорномор'я становила 79,1 \% видів адвентивної фракції. Згідно з отриманими даними, цей показник нині становить лише $52,4 \%$.

Порівняно $з$ даними 35-річної давнини, частка видів у інших групах адвентивної фракції (агріофіти, ергазіофіти, ефемерофіти) - суттєво збільшилася. Так, для флори малих річок ПЛЛ. Причорномор'я наводилося лише три агріофіти, в той час як зараз 13-19 видів. Для флори малих річок зафіксовано зростання 39 агріофітів, або 31,0 \% видів адвентивної фракції флори досліджених річок.

Як було показано раніше, 126 видів адвентивної фракції флори малих річок становлять 64,3 \% обсягу цієї фракції пониззя межиріччя Дністер - Тилігул [7], що складає лише 22,3 \% видів адвентивної фракції флори Північного Причорномор'я [17]. 
У апофітних фракціях флор всіх малих річок, за кількістю видів, домінуе група геміапофітів: від 22,1 \% у флорі Балай, до 27,0 \% у флорі Великий Куяльник. Ці дані є дещо вищими проаналізованої флори долин невеликих річок в цілому $-21,3 \%$. Для флори ж межиріччя загалом цей результат становить лише $18,3 \%$.

Таким чином, серед апофітної фракції спостерігається домінування видів, які активно поширюються на трансформованих екотопах, проте утримують свої позиції і у природній флорі.

Розподіл видів адвентивної фракції за хронотипом є доволі неоднозначним: у флорі річки Великий Куяльник переважають кенофіти, у флорах інших річок - археофіти. У загальній флорі малих річок частки видів у вказаних групах - практично однакові, хоча у флорі пониззя межиріччя Дністер - Тилігул відмічено незначне переважання кенофітів (на 2,0 \%). Проте, в цілому, для флори Північного Причорномор'я характерна значна частка кенофітів [17].

Оскільки частка синантропних видів у досліджуваному регіоні перевищує $50 \%$, слід констатувати уніфікацію флори та їі перетворення у штучну. Однак, відновлення порушених екотопів, зменшення або припинення антропогенного впливу на природні ділянки може сприяти появі у долинах малих річок регіону резерватів природної флори.

\section{Висновки}

1. У дослідженому регіоні виділено 522 види рослин, з яких 291 вид є синантропним, що складає 55,7 \% від загальної кількості видів флори пониззя межиріччя Дністер-Тилігул.

2. Найбільшою кількістю видів представлена синантропна флора долини p. Великий Куяльник $(61,8$ \%), найменшою - p. Тилігул $(51,9$ \%).

3. За хронотипом у долинах всіх річок, крім Великого Куяльника, переважають археофіти, хоча у загальній флорі досліджуваного регіону кенофітів на $2 \%$ більше.

4. Виділено 25 видів рослин з 12 родин, що можуть також вважатися синантропними для досліджених флор чотирьох річок.

5. Загальною тенденцією у досліджуваних флорах $€$ переважання видів апофітної фракції, в якій домінують види, що активно поширюються на трансформованих екотопах, зберігаючи свої позиції у природній флорі (геміапофіти); у фракції адвентивних видів - рослини, які заселяють переважно трансформовані екотопи (епекофіти).

6. Через значну трансформацію екотопів досліджені флори набули уніфікованого вигляду та стали штучними, хоча при зменшенні антропогенного впливу можлива поява осередків природної флори. 


\section{Список використаної літератури}

1. Бондаренко Е. Ю. Инвазионные виды во флоре экотопов различных секций антропогенных экосистем / Е. Ю. Бондаренко, Т. В. Васильева // Мониторинг и оценка состояния растительного мира: IV междунар. науч. конф.: матеріали конф. - Минск: ГУ «БелИСА», 2013. - С. 172-174.

2. Бондаренко Е. Ю. Инвазионные виды растений во флорах побережий лиманов и малых рек юга Одесской области / Е. Ю. Бондаренко // Proceedings of the VI International Young scientists conference «Biodiversity. Ecology. Adaptation. Evolution» dedicated to 150 anniversary from the broth of famous botanist Vladimir Lipskiy (Odessa, May 13-17, 2013): tez. - Odessa: Pechathiy dom, 2013. - C. 12-13.

3. Бондаренко Е. Ю. Инвазионные виды растений во флоре междуречья Днестр - Тилигул / Е. Ю. Бондаренко, Т. В. Васильева // Актуальные проблемы экологии: IV Всерос. науч. конф. «Актуальные проблемы экологии и сохранения биоразнообразия России и сопредельных территорий». Сев.-Осет. гос. ун-т им. К. Л. Хетагурова: матер. конф. - Владикавказ: Изд-во СОГУ, 2013. - С. 34-40.

4. Бондаренко Е. Ю. Характеристика синантропных видов растений флоры низовий междуречья Днестр Тилигул (Одесская область, Украина) / Е. Ю. Бондаренко, Т. В. Васильева // Научные ведомости Белгородского государственного университета. - 2011. - Серия: Естественные науки. - Т. 3 (98). - Выпуск 14/1. - C. 238-241.

5. Бондаренко О. Ю. Види - учасники демутаційних процесів пониззя межиріччя Дністер - Тилігул / О. Ю. Бондаренко, Т. В. Васильєва // II відкритийз’їзд фітобіологів Херсонщини (Херсон, 15 травня 2008): тези доповідей. - Херсон: Айлант, 2008а. - С. 16-18.

6. Бондаренко О. Ю. Зміна еколого-ценотичної структури покинутих агроугідь півдня України. /О.Ю.Бондаренко, Т. В. Васильєва // Відновлення порушених природних екосистем: III міжнар. наук. конф. (м. Донецьк, 7-9 жовтня 2008 р.): матер. конф. - Донецьк, 2008б. - С. 77-80.

7. Бондаренко О. Ю. Конспект флори пониззя межиріччя Дністер - Тилігул / О. Ю. Бондаренко. - Київ: Фітосоціоцентр, 2009. - 332 с.

8. Бурда Р. И. Антропогенная трансформация флоры / Р. И. Бурда. - Киев: Наук. думка, 1991. - 167 с.

9. Бурда Р. I. Застосування методики оцінки антропотолерантності видів вищих рослин при створенні «Екофлори України» / Р. І. Бурда, Я. П. Дідух // Укр. фітоцен. зб. - Серія С. - Т. 1, № 20. - Київ, 2003. C. 34-44.

10. Васильєва-Немериалова Т. В. Синантропна флора припортових міст Північно-Західного Причорномор'я та шляхи ії розвитку: автореф. дис. на здобуття наук. ступеня канд. біол. наук: спец. 03.00.05. "Ботаника"/ Т. В. Васильєва-Немерцалова - Київ, 1996. - 22 с.

11. Дидух Я. П. Растительный покров Горного Крыма (структура, динамика, эволюция и охрана) /Я. П. Дідух. - Киев: Наук. думка, 1992. - 256 с.

12. Дідух Я. П. Геоботанічне районування України та суміжних територій / Я. П. Дідух, Ю. Р. ШелягСосонко // Укр. ботан. журн. - 2003. - Т. 60, № 1. - С. 6-17.

13. Дубина Д. В. Синантропна флора угруповань інтразональної рослинності Північного Причорномор'я / Д. В. Дубина, П. А. Тимошенко // Чорномор. ботан. журн. - 2005. - Т. 1, № 2. - С. 33-46.

14. Дубына Д. В. Плавни Причерноморья / Д. В. Дубына, Ю. Р. Шеляг-Сосонко. - Киев: Наук. думка, 1989. $272 \mathrm{c}$.

15. Екологічні проблеми. Звіт про стан навколишнього природного середовища в Одеській області у 2004 році // Причорноморський екологічний бюлетень. - 2005. - Т. 2 (16). - С. 106-115.

16. Мойсієнко I. I. Адвентивний елемент флори Північного Причорномор'я / I. I. Мосієнко // Біологічні системи, 2010. - Т. 2, № 3. - С. 69-73.

17. Мойсієнко I. I. Флора Північного Причорномор'я (структурний аналіз, синантропізація, охорона): автореф. дисертації на здобуття наук. ступеня док. біол. наук: 03.00.05 «ботаніка» / Іван Іванович Мойсієнко. Київ, 2011. - 35 с.

18. Мойсієнко I. I. Флористичне багатство та систематична структура флори Північного Причорномор'я / I. I. Мойсієнко // Чорноморськ. ботан. ж. - 2013. - Т. 9, № 1. - С. 41-56.

19. Определитель высших растений Украины / Д. Н. Доброчаева, М. И. Котов, Ю. Н. Прокудин. - Киев: Наукова думка, 1987. - 548 с.

20. Природа Одесской области. Ресурсы, их рациональное использование и охрана. - Киев-Одесса: Вища школа, 1979. - $144 \mathrm{c}$.

21. Протопопова В. В. Інвазійні види у флорі Північного Причорномор'я / М. В. Шевера, С. Л. Мосякін, В. А. Соломаха, Т. Д. Соломаха, Т. В. Васильєва, С. П. Петрик. - Київ: Фітосоціоцентр, 2009. - 56 с.

22. Протопопова В. В. Синантропная флора Украины и пути её развития / Вера Викторовна Протопопова. Киев: Наук. думка, 1991. - 192 с. 
23. Рослинний світ. Звіт про стан навколишнього природного середовища в Одеській області у 2004 році (2005) // Причорноморський екологічний бюлетень. - Т. 2 (16). - С. 82-88.

24. Швебс Г. I. Каталог річок і водойм України: Навчально-довідковий посібник / Г. І. Швебс, М. I. Ігошин. Одеса: Астропринт, 2003. - 392 с.

25. Юриев Б. А. Флора как базовое понятие флористики: содержание понятия, подходы к изучению Б. А. Юрцев // Теоретические и методические проблемы сравнительной флористики: II раб. совещ. по сравнит. флористике. Неринга, 1983: матер. конф. - Ленинград: Наука, 1987. - С. 13-28.

26. Jäger E. J. Möglichkeiten der Prognose synanthroper Pflanzenausbreitungen / E. J. Jäger // Flora. - 1988. V. 180. - C. 101-131.

27. Mosyakin S. L. Vascular Plants of Ukraine. A nomenclature Checklist / S. L. Mosyakin, M. M. Fedoronchuk. Kiev, 1999. - $345 \mathrm{p}$

28. Moysiyenko I. I. The flora of Kurgans in the Desert Steppe Zone of Southern Ukraine / I. I. Moysiyenko, B. Sudnik-Wójcikowska // Чорноморськ. бот. ж. - 2006. - T. 2, № 1. - C. 5-35.

29. Pyšek Petr. How reliable era data on alien species in Flora Europeae? / Petr Pyšek // Flora. - 2003. - T. 198. C. 499-505.

Стаття надійшла до редакції 14.03.2015

\section{Е. Ю. Бондаренко, Т. В. Васильева}

Одесский национальный университет им. И. И. Мечникова, кафедра ботаники, ул. Дворянская, 2, Одесса, 65082, Украина

\section{СТРУКТУРА СИНАНТРОПНОЙ ФЛОРЫ МАЛЫХ РЕЧЕК НИЗОВИЙ МЕЖДУРЕЧЬЯ ДНЕСТР - ТИЛИГУЛ}

\section{Резюме}

Установлены особенности синантропной флоры долин четырех малых речек в низовьях междуречья Днестр - Тилигул. Выявлен 291 вид синантропных растений $(55,7$ \% общего количества видов). В долине реки Большой Куяльник произрастает наибольшее количество синантропных видов $(61,8 \%)$, в долине р. Тилигула - наименьшее (51,9 \%). Во всех флорах, количественно, преобладают виды апофитной фракции (31,7 \% - 38,5 \%). Все исследованные флоры можно охарактеризовать как трансформированные.

Ключевые слова: синантропная флора, малые речки, низовья Днестр - Тилигул.

\section{O. Yu. Bondarenko, T. V. Vasylyeva}

Odesa National Mechnykov University, Department of Botany

2, Dvoryanska str., Odesa 65082, Ukraine, e-mail: tvas@ukr.net

\section{STRUCTURE OF SYNANTHROPIC FLORA OF SMALL RIVERS OF THE DNIESTER - TILIGUL LOWER REACHES INTERFLUVE}

It was considered the peculiarities of synanthropic flora of four small rivers valleys in the Dniester - Tiligul lower reaches interfluve. There were found 291 species of synanthropic plants (55\% from all region species). The most of them $(61.8 \%)$ are in Large Kujalnik valley, the less $(59.1 \%)$ - in Tiligul valley. In all floras the species of apophytes fraction prevail $(31.7 \%-38.5 \%)$. So the explored floras may be characterized as transformed.

Key words: synanthropic flora, small rivers, lower reaches, Dniester, Tiligul. 